\title{
ALTERNATIVES OF DOMESTIC WASTEWATER SLUDGE DRYING PROCESSES FOR ENERGY RECOVERY : A REVIEW
}

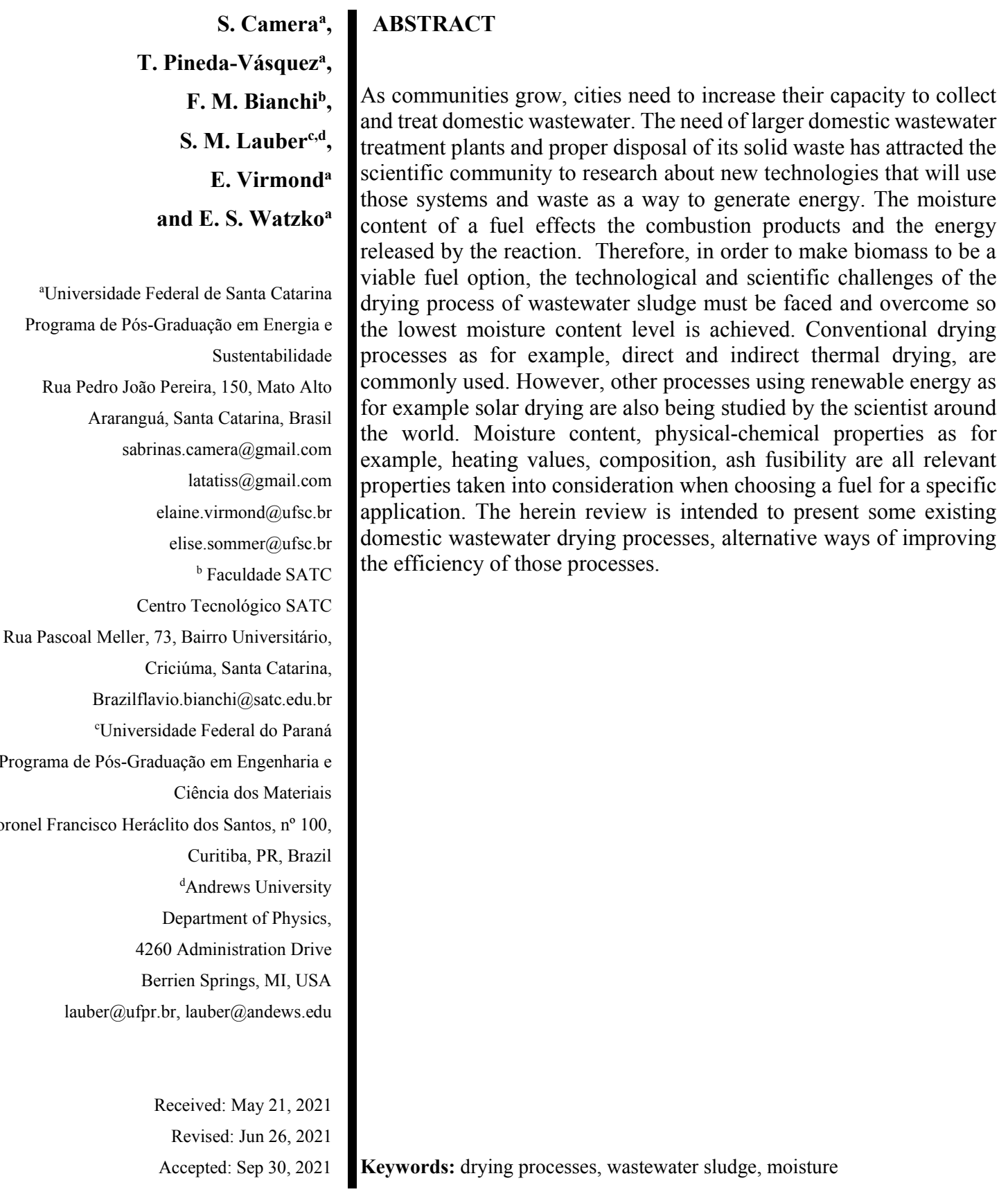

NOMENCLATURE

US EPA - United States Environmental Protection Agency

\section{INTRODUCTION}

The inadequate disposal of the sludge from domestic wastewater treatment plants is puts the 
environment in danger due to its pathogenicity and due to presence of contaminants.

Logistics is also an issue, since high cost is associated to the large amount of sludge that must be transported, stored and disposed. According to Werther and Ogada (1999), domestic sludge can be used as a fertilizer or used as fuel for heat generation. Those are options have the potential to be explored since landfills are common in Brazil (Bringhenti et al., 2018).

Chemical and biological components of domestic wastewater may vary. According to Luts et al. (2000) the composition of domestic waste water is $99.99 \%$ of water and $0.01 \%$ of solid. Of those $0.01 \%$ of solid, $70 \%$ are organic and $30 \%$ are inorganic solid.

According to Savi et al. (2020), biomass generated from wastewater sludge can be used to produce biofuels and bioenergy, as for example, biogas and its use to generate electricity at the treatment plant.

There is also the possibility of applying thermochemical processes to recover the energy for the sludge. However, cost effective ways of reducing the amount of moisture of the sludge must be found.

The herein study has the objective to present alternatives presented by the scientific community to reduce the moisture of domestic wastewater sludge aiming its use in energy recovery.

\section{GENERATION AND STORAGE OF} WASTEWATER SLUDGE

According to the Diagnose of Water and Wastewater Services performed by the Brazilian National System of Information in 2018 (Brasil, 2019), the wastewater treatment system had opened 1.3 million of new plants, indicating $4.2 \%$ growth comparing to the previous year.

In $2018,74.5 \%$ of all the wastewater generated in Brazil was collected and only $46.3 \%$ was treated, the equivalent of 4.18 billion of $\mathrm{m}^{3}$ for the year of 2017 and 4.3 billion of $\mathrm{m}^{3}$ for the year of 2018, an increase of $2.9 \%$ (Brasil, 2019).

According to Batista (2015), 20-35g of solid waste from the aerobic treatment is produced from anaerobic treatment and $3-15 \mathrm{~g}$ is produced from wastewater treatment plant per capita.

The toxic and pollutant components of the wastewater sludge make it an environmental problem, the high cost associated to its allocation and treatment make it an economic issue, since it represents $35-50 \%$ of all costs of the treatment plant. (Velden et al., 2008).

The location where the wastewater treatment plant will be placed must have a large amount of available land which has becoming more and more hardto be found. The project of the treatment plant must have provision for residue elimination and full elimination of pathogenic components.
Pyrolysis is a process by which heat is provided in absence of oxygen and the biomass is thermally decomposed in three components: i) solids (carbon residue, combustible material); ii) liquid (bio-oil) and iii) gases (mixture of combustible gases). In the gasification process, there is the thermochemical conversion of a material into combustible gases and ashes. The combustible products of pyrolysis and gasification can then be burnt and the heat generated used to dry the sludge.

\section{MOISTURE REDUCTION OF DOMESTIC WASTEWATER SLUDGE}

Pre-treatment of solids is essential for its use as an alternative source of energy. Moisture is not only relevant from the energetic point of view but it is also relevant when considering transportation and storage (Simão, 2011). Reduction on moisture content will reduce volume and cost, since both are proportionally related storage and transport. Thermochemical conversion is more effective when moisture content is low. Domestic wastewater sludge must be composed of $28-33 \%$ of solid for the biomass to be burnt without the addiction of any other fuel (Bennamoun et al., 2013; Batistella et al., 2015).

The dehydrated wastewater sludge, even after centrifugation, can still have humidity ranging from 70 wt.\% to 90 wt. \%t, which makes the direct energy recovery unfeasible (Bianchini et al., 2015; KijoKleczkowska et al., 2016; Nathanson e Ambulkar, 2020).

Lignin is a solid byproduct of the bioethanol production and is impregnated in the space between the porous of wastewater sludge to produce hybrid fuels. According to Park et al. (2019) the sludge must go through a drying process for $24 \mathrm{~h}$ at $105^{\circ} \mathrm{C}$ to remove enough moisture to make the lignin impregnation viable.

\section{SLUDGE DRYING PROCESSES}

According to Khanlari, et al. (2020) an effective sludge drying process requires a significant amount of energy. However, there are energy conversion methods that can be used to recover energy from other processes that would be wasted.

Not all the materials need to go through the drying process, but for those that do, exhaustion gases from the combustion of other processes can be used as heat source to dry them and remove moisture (Dias et al., 2012). According Uasuf and Becker (2011), drum dryer motors can use exhaustion gases as heat source for the drying process. The cost for this type of process is associated to the amount of sludge to be dried.

Calvo et al. (2013) conducted their research using a fuel composed of $60 \%$ of forest biomass and 40 wt. $\%$ of wastewater sludge. Before their being 
mixed, the fuels were air-dried. The forest biomass moisture content was reduced to $5.82 \%$ and the sludge moisture reached 3.85 wt. $\%$.

According to Bennamoun et al. (2013), the convective drying is performed in two stages: a stage where the drying rate is constant and a phase of decreasing drying rate. Several parameters influence the kinetics of the process as for example, the type of the domestic sludge.

The most common convective dryers are: belt dryers, flash dryers, fluidized bed dryers and rotary dryers. The energy consumption varies according to the type of drier from $700 \mathrm{kWh}$ to $1400 \mathrm{kWh}$ per ton of evaporated water. The specific drying rate also varies from $0.2 \mathrm{~kg} / \mathrm{m}^{2} \mathrm{~h}$ (flash dryer) to $30 \mathrm{~kg} / \mathrm{m}^{2} \mathrm{~h}$ for belt dryers (Bennamoun et al., 2013).

Convective drying is the physical concept applied to biodrying, in which heat is generated from biodegradation of organic matter facilitated by mechanically controlled aeration (Cai et al., 2012). The aeration controls the temperature of the stack improving the evaporation of the water in the sludge (Cai et al., 2012).

Bianchini et al. (2015) proposed a study where the heat for the drying process is from the exhaustion gases without using heat exchangers from a power plant. This concept aims to reduce the moisture content of the domestic sludge in $75 \mathrm{wt} \%$.

With the intent of reducing energy consumption and investment in equipment, Zhu et al. (2012) studied the efficiency of drying at low temperature $\left(150{ }^{\circ} \mathrm{C}\right.$, $175^{\circ} \mathrm{C}$ e $200{ }^{\circ} \mathrm{C}$ ) for different shapes of sludge samples: cake, cylindrical and spherical. The studied pointed out that the cake shape had the highest drying efficiency. Due to the specific surface, the spherical shape presented the lowest drying efficiency. The highest efficiency was $40 \%$ reached in $3 \mathrm{~h}$ of drying at $200^{\circ} \mathrm{C}$.

Avelar et al. (2018) investigated a drying system of industrial sludge using hot gases from a coal furnace at $100 \pm 20{ }^{\circ} \mathrm{C}$. They also used eucalyptus chips, which improved the efficiency of the drying system.

Fluidized bed dryers, rotary drum dryer and continuous flow dryer are examples of direct contact dryers. Since those technologies use a mixture of combustion gases and water vapor, they generate an expressive amount of organic vapor. In indirect contact dryers, the thermal energy from the exhaustion gases are transferred to the sludge by a heating surface. The combustion gases and vapors are exhausted through a separated pathway, making the treatment of the emissions easier to be done (Brechtel et al., 1990).

Batistella et al. (2015) studied the gaseous emissions generated by the combustion of an anaerobic sewage sludge in a moving bed reactor. They showed that the level of $\mathrm{CO}$ was within the emission legal limits during the combustion process.
They showed there was an increase of $\mathrm{CO}$ concentration in the drying process due to high level of oxygen and high temperature $\left(353.95 \pm 18.25^{\circ} \mathrm{C}\right)$. The $\mathrm{SO}_{2}$ concentration was higher than the other pollutants, probably due to the high sulfur content of the sludge.

\section{ALTERNATIVE DRYING PROCESSES}

Fry-drying is a technique that provides a quick evaporation and a high humidity content. This process uses the process of "frying" for approximately 10 minutes in oil at $150^{\circ} \mathrm{C}$. The sludge is molded in a pre-determined size, shape and thickness and placed in a conveyor belt submerged in oil. The velocity of the belt and the supplied amount of sludge is controlled by the system; therefore, the time of immersion is also controlled. The vapor generated that dragged oil generated during the process are then condensed, and passed through a separation process where the oil is collected and reused (Chae et al., 2016).

Through this method the lower heating value heat value of the sludge was increased and the humidity levels were low, below 5\% (Chae et al., 2016).

Bennamoun et al. (2013) presents a study about the combination of air and solar drying. Those methods depend on the climate condition, as for example solar radiation and air temperature, and require energy between $30 \mathrm{KWh}$ and $200 \mathrm{kWh}$ to evaporate one ton of water.

Solar heater can be used to heat the air supplied to the drying process of wastewater sludge. Moreover, other processes can be combined to provide pre-heated air (Tuncer et al., 2020).

Mathioudakis et al. (2013) develop a system where solar concentrators are used to accelerate the evaporation rate of water taking advantage of the artificial greenhouse effect promoting nonequilibrium condition between the vapor pressures which is controlled by the inlet air. The main component of this process is where the wastewater sludge mixes with air. The humid air is removed from the mixture at a rate of $5,000 \mathrm{~m}^{3} / \mathrm{h}$.

\section{PROPERTIES OF WASTEWATER SLUDGE FROM DRYING PROCESSES}

Avelar et al. (2018) reported that the drying process of a mixture of $75 \%$ sludge and $25 \%$ of eucalyptus bark using hot gases from a furnace at $0.64 \pm 0.02 \mathrm{~m}^{3} / \mathrm{s}$ and $100 \pm 20^{\circ} \mathrm{C}$, presented a better dying rate, which made the solid content to increase from $31 \%$ to $72 \%$, during a period of $5 \mathrm{~h}$.

One of the advantages of using drying by heat compared to other drying processes is the improvement of biosolids, since drying by heat is the 
good for production of biosolids of Class A, eliminating pathogens, including viruses (EPA, 2020).

Mathioudakis et al (2013) demonstrated in their research in Greece that due to water evaporation, the sludge reduced its volume significantly to $90 \%$. The sludge cake became sludge granules with $10-15 \%$ reduction in humidity. The volatile fraction increased from $56.8-66.8 \%(\mathrm{w} / \mathrm{w})$ of dry solid content. The level of fecal coliform was reduced three orders of magnitude, which demonstrated that the process also caused some level of sludge sanitization.

More studies are required to determine the physical-chemical properties, elementary composition, thermal behavior, composition and ash fusibility) of the material so it can be used in energy applications as reported by Virmond et al. (2012) about other fuels from biomass.

Batistella et al. (2015) reported some wastewater properties: lower heating value of $14.55 \mathrm{MJ} / \mathrm{kg}$ and higher hating value of $16.19 \mathrm{MJ} / \mathrm{kg}$; composition of the dry material of $33.87 \%$ of carbon, $33.87 \%$ of hydrogen, $5.88 \%$ of nitrogen and $0.67 \%$ of sulfur.

\section{CONCLUSION}

The processes of pre-treatment are essential to make the energy recovery of the wastewater sludge possible.

We emphasize that the drying process has a huge impact on energy consumption of on the fuel production processes from wastewater sludge.

Drying processes using exhaust gases can be a viable alternative for energy recovery, however this possibility is little explored. Renewable energy sources, as solar energy for example, has the potential to be more wildly used and increase the overall efficiency of the system.

After the dying process, the wastewater sludge showed to have high levels of sanitization, reducing the amount of pathogens. That is a positive, promising and extremely relevant result, specially in midst of the Coronavirus pandemics.

\section{ACKNOWLEDGEMENTS}

The authors would like to thank the support of Coordenação de Aperfeiçoamento de Pessoal de Nível Superior (CAPES).

\section{REFERENCES}

Avelar, N. V. et al., 2018, Thermal drying of industrial sludge using forced aeration. Environmental Technology, [S.L.], Vol. 40, n. 25, p. 3297-3307. Informa UK Limited. http://dx.doi.org/10.1080/09593330.2018.1470679.

Disponível

em:

https://www.tandfonline.com/doi/full/10.1080/09593

330.2018.1470679. Acesso em: 28 nov. 2020.
Batista, L. F., 2015, Lodos Gerados Nas Estações De Tratamento De Esgotos No Distrito Federal: Um Estudo De Sua Aptidão Para O Condicionamento, Utilização E Disposição Final. 2015. Dissertação (Mestrado) - Curso de Tecnologia Ambiental e Recursos HÍdricos, Departamento de Engenharia Civil e Ambiental, Universidade de Brasília, Brasília. Disponível em: http://ptarh.unb.br/wpcontent/uploads/2017/03/PUBL ICA $\%$ C3\%87\%C3\%83O-PTARH.DM-

\%E2\%80\%93-1682015.pdf. Acesso em: 21 dez. 2019.

Batistella, L. et al., 2015, Gaseous emissions from sewage sludge combustion in a moving bed combustor. Waste Management, [S.L.], Vol. 46, p. 430-439.

http://dx.doi.org/10.1016/j.wasman.2015.08.039. Disponível em: https://www.sciencedirect.com/science/article/pii/S0 956053X15301069. Acessoem: 19 jun. 2020.

Bennamoun, L. et al., 2013, Review on fundamental aspect of application of drying process to wastewater sludge. Renewable And Sustainable Energy Reviews, [S.L.], Vol. 28, p. 29-43. http://dx.doi.org/10.1016/j.rser.2013.07.043.

Disponível em: https://www.sciencedirect.com/science/article/pii/S1 364032113004887. Acesso em: 04 dez. 2020

Bianchini, A. et al., 2015, Sewage sludge drying process integration with a waste-to-energy power plant. Waste Management, [S.L.], Vol. 42, p. 159165.http://dx.doi.org/10.1016/j.wasman.2015.04.020. Disponível em: https://www.sciencedirect.com/science/article/pii/S0 956053X15003153. Acesso em: 08 dez. 2020.

BRASIL. Sistema Nacional de Informações: Diagnóstico de Serviços de Água e Esgoto - 2018. Brasília, 2019. b. Disponível em: $<$ http://www.snis.gov.br/diagnosticos $>$ Acesso em: 06jun. 2020.

Brechtel, H. et al., 1990, Improved Efficiency of Sewage Sludge Incineration by Preceding Sludge Drying. Water Science And Technology, [S.L.], Vol. 22 , n. 12, p. 269-276. IWA Publishing. http://dx.doi.org/10.2166/wst.1990.0121. Disponível em: $\quad \mathrm{https}: / /$ iwaponline.com/wst/articleabstract/22/12/269/23772/Improved-Efficiency-ofSewage-SludgeIncineration?redirectedFrom=fulltext. Acesso em: 08 dez. 2020.

Bringhenti, J. R. et al., 2018, Codisposição de lodos de tratamento de esgotos em aterros sanitários brasileiros: aspectos técnicos e critérios mínimos de aplicação. Engenharia Sanitaria e Ambiental, [S.L.], 
Vol. 23, n. 5, p. 891-899. FapUNIFESP (SciELO). http://dx.doi.org/10.1590/s1413-41522018124980.

Disponível em: https://www.scielo.br/pdf/esa/v23n5/1809-4457-esas1413-41522018124980.pdf. Acesso em: 17 jan. 2021.

Cai, Lu et al., 2012, Moisture variation associated with water input and evaporation during sewage sludge bio-drying. Bioresource Technology, [S.L.], Vol. 117, p. 13-19. http://dx.doi.org/10.1016/j.biortech.2012.03.092.

Disponível em: https://www.sciencedirect.com/science/article/pii/S0 960852412005561? casa token $=$ nJxVMVA2ZnAAA AAA:GAb_101fEemofBXeuxYc4iyt3bu8Wa89XX W4QqXgSÖUSsg6LunG-

ZGsLTVXDTJyPyhBimnRXdg. Acessoem: $10 \mathrm{dez}$. 2020.

Cai, Lu et al., 2013, Influence of forced air volume on water evaporation during sewage sludge bio-drying. Water Research, [S.L.], Vol. 47, n. 13, p. 4767-4773.

http://dx.doi.org/10.1016/j.watres.2013.03.048.

Disponível em:

https://www.sciencedirect.com/science/article/pii/S1 878029612005907. Acessoem: 12 dez. 2020.

Calvo, A.I. et al., 2013, Particulate emissions from the co-combustion of forest biomass and sewage sludge in a bubbling fluidized bed reactor. Fuel Processing Technology, v. 114, p. 58-68. Disponível em:

https://www.sciencedirect.com/science/article/pii/S0 378382013001252. Acesso em: 05 dez. 2020.

Chae, J. et al., 2016, Experimental study of frydrying and melting system for industrial wastewater sludge. Journal Of Hazardous Materials, [S.L.], v. 313, p. 78-84. http://dx.doi.org/10.1016/j.jhazmat.2016.03.084.

Disponível em: https://www.sciencedirect.com/science/article/pii/S0 304389416303077. Acesso em: 06 dez. 2020.

Dias, J. M.C.S., et al., 2012, Produção de briquetes epéletes a partir de resíduos agrícolas, agroindustriais e florestais. Brasília, DF: Embrapa Agroenergia, p. 1-130. Disponível em: $<$ https://ainfo.cnptia.embrapa.br/digital/bitstream/ite m/78690/1/DOC-13.pdf>. Acessoem: 04 out. 2019.

EPA. Biosolids Technology Fact Sheet: heat drying. Heat Drying. 2020. Disponível em: https://www.epa.gov/sites/production/files/201811/documents/heat-drying-factsheet.pdf. Acesso em: $11 \mathrm{dez} .2020$.
Khanlari, A. et al., 2020, Energetic, environmental and economic analysis of drying municipal sewage sludge with a modified sustainable solar drying system. Solar Energy, [S.L.], v. 208, p. 787-799.

http://dx.doi.org/10.1016/j.solener.2020.08.039.

Disponível em: https://www.sciencedirect.com/science/article/pii/S0 038092X2030877X. Acessoem: 05 dez. 2020.

Kijo-Kleczkowska, A. et al., 2016, Experimental research of sewage sludge with coal and biomass cocombustion, in pellet form. Wast Management, [s. 1.], Vol. 53, p. 165-181. Disponível em: http://www.sciencedirect.com/science/article/pii/S09 56053X16301842. Acessoem: 09 out. 2019.

Luts, D et al., 2000, Co-incineration of dried sewage sludge in coal-fired power plants: A case study. Water Science and Technology, Vol. 42, 1 nov. 2000. DOI 10.2166/wst.2000.0221

Mathioudakis, V. L. et al., 2013, Sewage Sludge Solar Drying: experiences from the first pilot-scale application in Greece. Drying Technology, [S.L.], Vol. 31, n. 5, p. 519-526. Informa UK Limited. http://dx.doi.org/10.1080/07373937.2012.744998.

Disponível

em: https://www.tandfonline.com/doi/full/10.1080/07373 937.2012.744998? casa token $=0$ bzlKhm3orAAAAA A\%3A6BnG66s6GkfpNN8DiizDwB1Z9KWPhvN20 iSnNmyqAxgVKI7ukD9pSWsljXpaH9gXtDCBwVr uwVaf7fE. Acessoem: 11 dez. 2020.

Park, J. et al., 2019, Two-in-One Fuel Synthetic Bioethanol-Lignin from Lignocellulose with Sewage Sludge and Its Air Pollutants Reduction Effects. Energies, [S.L.], Vol. 12, n. 16, p. 3072. http://dx.doi.org/10.3390/en12163072. Disponível em: https://searchproquest.ez46.periodicos.capes.gov.br/engineeringjo urnals/docview/2317017609/fulltextPDF/8FAC76F1 5F6D4E41PQ/1?accountid=26642. Acesso em: 29 nov. 2020.

Savi, V. G.; Geremias, R.; Virmond, E.; Janke, L., 2020, Potencial de geração de energia elétrica e emissões evitadas de CO2 pelo uso de biogás gerado em estação de tratamento de esgoto: um estudo de caso. Espaço Energia - Brazilian Open Journal of Energy, Vol. 1, p. 1-10.

Simião, J., 2011, Gerenciamento de resíduos sólidos industriais em uma empresa de usinagem sobre o enfoque de uma produção mais limpa. $170 \mathrm{f}$. Dissertação (Mestrado) - Curso de Engenharia, Universidade de São Paulo, São Carlos, 2011. Disponível em: $<$ http://www.teses.usp.br/teses/disponiveis/18/18138/ 
tde-13072011-100539/pt-br.php>. Acessoem: 08 out. 2019.

Tuncer, A. D. et al., 2020, Testing of a novel convex-type solar absorber drying chamber in dehumidification process of municipal sewage sludge. Journal Of Cleaner Production, [S.L.], Vol. 272, p. 122862 . http://dx.doi.org/10.1016/j.jclepro.2020.122862. Disponível em: https://www.sciencedirect.com/science/article/pii/S0 959652620329073. Acesso em: 06 dez. 2020.

Werther, J., Ogada, T., 1999, Sewage sludge combustion. Progress In Energy And Combustion Science, [S.L.], Vol. 25, n. 1, p. 55-116. http://dx.doi.org/10.1016/s0360-1285(98)00020-3.

Disponível em: https://www.sciencedirect.com/science/article/pii/S0 360128598000203. Acessoem: 17 jan. 2021.

Uasuf, A.; Becker, G., 2011, Wood pellets production costs and energy consumption under different framework conditions in Northeast Argentina. Biomass and Bioenergy, [s. 1.], Vol. 35, n. 3, p. 1375-1366. Disponível em: $<$ https://www.sciencedirect.com/science/article/pii/S $0961953410004873>$. Acesso em: 03 out. 2019.

Velden, M. V. et al., 2008, The distribution of heavy metals during fluidized bed combustion of sludge (FBSC). Journal of Hazardous Materials, [s.l.], Vol. 151, n. 1, p.96-102. Elsevier BV. DOI: http://dx.doi.org/10.1016/j.jhazmat.2007.05.056.

Disponível em: https://www.sciencedirect.com/science/article/pii/S0 304389407007741. Acessoem: 15 mar. 2020.

Virmond, E. et al., 2012, Characterisation of agroindustrial solid residues as biofuels and potential application in thermochemical processes. Waste Management, [S.L.], Vol. 32, n. 10, p. 1952-1961. Elsevier BV. http://dx.doi.org/10.1016/j.wasman.2012.05.014. Disponível em: https://www.sciencedirect.com/science/article/pii/S0 956053X12002231. Acessoem: 20 jan. 2021.

Virmond, E. et al., 2013, Valorization of agroindustrial solid residues and residues from biofuel production chains by thermochemical conversion: a review, citing Brazil as a case study. Brazilian Journal of Chemical Engineering, [s. 1.], v. 30, n. 2, p. 197$230 . \quad$ Disponível em: $<$ http://www.scielo.br/scielo.php?script=sci_arttext\& pid=S0104-66322013000200001\&lng=en\&tlng=en $>$. Acesso em: 3 set. 2019.

\footnotetext{
Zhu, Fenfen et al., 2012, The Study of Sewage Sludge Thermo-Drying Efficiency. Procedia Environmental Sciences, [S.L.], Vol. 16, p. 363-367.
}

Elsevier BV. http://dx.doi.org/10.1016/j.proenv.2012.10.052. Disponível em: https:/www.sciencedirect.com/science/article/pii/S 1878029612005907. Acessoem: 12 dez. 2020. 